\title{
1. Negotiating the sacred in multicultural societies
}

\section{Elizabeth Burns Coleman and Kevin White}

The social costs of increasing antagonism, fear and social dislocation on the basis of religious persuasion suggest that Australia, as well as other multicultural societies, needs to re-examine the place of religion in society, the causes of social discontent, as well as the various means by which religious differences may be negotiated peaceably. Such an examination requires information from a wide variety of perspectives, and discussion at all levels of society. The purpose of this volume is to make a contribution to this discussion by providing a rich, multifaceted exploration of the issue. It brings together religious and secular perspectives and the insights of scholarship from a wide variety of disciplines. It explores histories of religious conflicts, our assumptions about secularisation, and examples of ways in which people of religious persuasions have, and can, negotiate religious difference. These issues have enormous practical significance in a multicultural society with diverse religious beliefs and cultural practices.

This book offers a unique contribution to this discussion because it attempts to engage with belief, not merely between faiths that can find some area of commonality, but between secular and religious perspectives. Importantly, it introduces new conceptions of blasphemy and sacrilege that explore them as broader, cross-cultural concepts that cannot be defined in terms of religious dogma and sentiment. A second way in which the book brings a unique perspective to bear on the issue of religious conflict is in its focus on negotiation. In political and social philosophy, religious belief is usually examined as a 'problem' of tolerance in a liberal democratic society. This book of essays seeks to move away from these traditional ways of discussing the issue, as they assume that religious commitment is intolerant, and cannot, and should not, be negotiated. The book addresses the issue of the nature of the sacred as part of the cultural reality of individuals' existences, and explores how the sacred has been contested, and negotiated between groups as part of a process in which agents make sense of the world, and seek to create order in it.

Blasphemy and sacrilege in modern societies cannot be considered as relics of the Middle Ages. Neither are they topics only of interest in relation to religious fundamentalism. In a society with a diverse religious and cultural make-up, such as contemporary Australia, there are inevitable clashes between conceptions of the sacred. What is held sacred by one group of people will not be sacred to another. In fact, what is sacred in one religion may be considered sacrilegious to another. 
A society's reaction to and management of blasphemy and sacrilege goes to its core, for it defines how it relates to its constituent groups, protecting difference or leaving the vulnerable to cope on their own. Yet we should be wary of assuming that this is an issue best addressed within the rubric of identity politics and the right to culture. For while we might agree that community is necessary for an individual's well-being, claims about religion as a cultural right fail to make a necessary distinction. There is a difference between having an ethnic or cultural identity and having a religious affiliation. While cultural affiliation is not a matter of choice, religious affiliation may be. We can, and often do, change our religious affiliation. Paradoxically, while we may change and adapt our cultural practices reasonably easily, we tend to think of our religious practices, once adopted, as stands that cannot be negotiated.

In this volume we do not set out to construct our present as an enlightened transformation out of the dark ages, nor to construct 'the other' - whether living in other countries or amongst us - as religious zealots and as totalitarian. A secular society risks limiting its understanding of itself if it reduces the terms of its discussion of these issues to the debates about free speech, or to the need to tolerate the irrational and incomprehensible beliefs of others. Neither paradigm provides a sufficiently rich vocabulary to address the content of the claims that are being made by believers. Debates over blasphemy law reduce blasphemy to 'offence'. The debates about toleration that assume religious belief is immune to reason limit our understanding of and interaction with those people who hold religious beliefs. Rather, this volume represents a collection of papers exploring how 'the sacred' is encountered, and negotiated, or fails to be negotiated, in a multicultural society.

\section{Secularisation and secularism}

Australia prides itself on its secularism. This does not mean that people do not profess to hold religious views. A sizeable minority of the population, 15.3 per cent, described themselves as non-religious in the 2001 census, however, the majority of Australians are Christians. The census showed that 67.3 per cent of Australians are Christians, and that Buddhism is the second largest religion in Australia, with 1.9 per cent of the population identifying themselves as Buddhist. The third, fourth and fifth largest religious categories are Islam (with 1.5 per cent of the population), Hinduism ( 0.5 per cent), and Judaism (0.4 per cent). In addition, many Aboriginal and Torres Strait Islander peoples maintain their traditional religious practices, or consider their traditional sacred sites a significant part of their heritage.

Australia may be said to be a secular society in two, quite different, ways. It may be described as a secular society in terms of its embrace of political secularism, which is reflected in the separation of religion from the state in Section 116 in the Constitution ${ }^{1}$ and in its embrace of the policy of 
multiculturalism. The Australian policy of multiculturalism appears to be the legacy of the political ideal of toleration. The basic tenet of toleration was a commitment to freedom of conscience. ${ }^{2}$ The ideal of multiculturalism is the respect for different ethnic, cultural and religious groups in society. The state makes a distinction between the roles of public citizens and their private beliefs, and maintains a commitment to freedom of religion. The second way in which Australia may be said to be a secular society is as a result of a social process of secularisation. The process of secularisation involves religious institutions losing public influence, a drop in attendance at religious ceremonies, and the loss of respect for religious symbols and specialists, such as clergy. The world-view of people in a secular society is increasingly rationalised and 'disenchanted'. Australia was secular in this second sense before it adopted a political policy of multiculturalism, and it is this second sense of secularism that is celebrated in its foundation myths of self-sufficient pioneers and working-class larrikins. ${ }^{4}$ One price of the process of secularisation is the confusion many people express about 'the place' of the sacred in our public lives. The sacred is held to be something of fundamental importance or value, and it has 'a place' in society to the extent that it is respected in our lives or has status within society. Blasphemy and sacrilege are both affronts to this value: they are acts of disrespect, irreverence, or destruction.

These two senses of secularism have become blurred in Australia's 'institutional norms' in relation to religion: religion is considered 'to be a "low-temperature" matter', not something to get over-enthusiastic about, and certainly not a trumpeted certainty. ${ }^{5}$ This institutional norm, or culture of secularism, tends to blind Australia's policy development in relation to cultural and religious diversity. As one social scientist has commented, when social issues are viewed through this perspective, 'religion cannot be a problem because it is, or should be, or shortly will be irrelevant' ${ }^{6}$ Unfortunately, such an attitude has become an unaffordable luxury. As Riaz Hassan demonstrates in this volume there is a complex relationship between modernity and religion, but the bottom line is that religion does not disappear, as social scientists through the 1950s, 60s and 70s predicted.

In contemporary Australia, blasphemy and sacrilege are on the rise as are deliberate assaults on other groups and their belief systems. ${ }^{7}$ Suzanne Rutland argues in this volume (chapter 2) that what we are witnessing is a clash of religious extremists, and a resurgence of extreme right-wing movements in Europe, America and Australia that are against both Judaism and Islam. The impact on the Jewish community in Australia has been significant, with five synagogues set fire, a Jewish kindergarten attacked, and bomb threats made against Jewish buildings. As she also points out, the Muslim community has been attacked, mosques set on fire, women's headdress has been pulled off in 
the street, as well as mosques being attacked and desecrated. The Jewish community's response has been one of increased vigilance, with the impact that this will have on the younger generation who stands guard around synagogues and Jewish buildings - of fear, apprehension and social exclusion.

\section{Understanding blasphemy}

In recent years, there has been significant debate about the role of blasphemy law in a multicultural society, and although some governments have considered abolishing elements of existing blasphemy laws, which only protect Christianity, there have also been suggestions that they should be extended to cover all religious groups. At the core of this debate is an important concern: how best to protect and respect religious pluralism, through freedom of speech or through the recognition and extension of blasphemy laws.

Understanding blasphemy poses an enormous challenge, largely because both its definition and our comprehension of its harm are generally understood within a legal framework. ${ }^{8}$ Laws against blasphemy and sacrilege are infrequently exercised in most Western democracies. Nonetheless, certain acts elicit strong public reactions and widespread debate. Recent famous cases include the fatwa issued against Salmon Rushdie for his novel Satanic Verses, and the attack on Andres Serrano's photograph 'Piss Christ' at the National Gallery of Victoria, with the subsequent closure of the exhibition. The extent that a liberal democracy should respect and engage with these religious sentiments presents an ongoing problem for any multicultural society. In law, blasphemy is prohibited as a form of libel within the criminal code. Its origins are from the ecclesiastical courts of the Star Chamber and the Court of High Commission. Since the early twentieth century, when it lost its connection with heresy and sedition under Australian law, blasphemy has been defined as vilification, ridicule and irreverence towards Christianity. As such, it is concerned with the manner rather than the matter (content) of something that is publicly spoken or published. Its primary purpose is understood to be the protection of the sentiments of Christians and the prevention of social disorder. ${ }^{9}$ As such, it might be thought that the primary moral wrong of an act of blasphemy involves giving offence.

Interestingly, however, the authors collected here who speak from a religious perspective have resisted interpreting blasphemy in terms protecting religious sentiment. Pringle specifically argues against this interpretation (chapter 3 ). She notes that it is almost universally agreed that blasphemy laws should be abolished. If their purpose is to protect the public order, and to protect Christians from outrage and insult, then there seems little point in keeping them. Blasphemy has become almost impossible to prove, and it is not clear what it is really protecting. The charge of blasphemy mounted by Bishop George Pell, in Melbourne, against Serrano's Piss Christ, was dismissed because it did not incite social unrest. The case mounted by Mary Whitehouse against Gay News for its 
publication of a poem and illustration of Christ's crucifixion, while in part based on the claim that it offended believers, was also based on the claim that it offended God. Pringle argues a belief in blasphemy ultimately relies on the belief that God can be offended. And she thinks that this is the case. Blasphemy is an offence to God which calls into question the ethical integrity of the world, and which has consequences that resonate through God and the world. Similarly, St John argues that blasphemy, which she develops as a category separate from specific belief systems, is the abandonment of a cardinal virtue common to all human beings, that is, the experience of awe which is central to the subjectivity of all peoples.

Like Pringle, Brady does not think blasphemy is a harm of offence to the believer, but in contrast, sees it as an act of denial (chapter 4). The existence of blasphemy is tied to the existence of the sacred, and where the latter does not exist, or is not accepted by the dominant group in society, then blasphemy occurs in the denial of the sacred as an aspect of human existence. Thus, Brady argues that the experience of the sacred is not tied to organised religion, but the sense of that which extends beyond the known world, mysterium tremendum et fascinans, and the failure to recognise this is in itself blasphemous. As Brady argues, contemporary Australia is materialistic, and (growing out of its origins in imperial expansion and domination) has an exploitative and utilitarian orientation to other peoples, the land and the future. As a result, rights, and the dignity of subordinate groups are ignored or denied, and enormous moral harm done both to those who are rejected and to the ethical being of those who reject them. As she puts it 'the growing coarseness, narrow-mindedness and violence, the paranoia and xenophobia evident around us today point to its consequences'.

For Rutland, it is not the agnostic or atheist who blaspheme, but the religious extremists and bigots who foster hatred and destruction. Yet, while there is disagreement between Rutland, Pringle, St John and Brady about which acts constitute blasphemy, all four interpretations seem to share a common theme: blasphemous acts constitute a disruption of 'right relations' in the world and a diminution of what it is to be fully human.

These authors should not be understood as promoting religious orthodoxy. Nor should they be thought of as undermining the political ideals of toleration, the secularisation of the state, or the policy of multiculturalism. Their interpretations of blasphemy operate beyond debates about the relationship between organised religion and the state, because they refuse to align the concept of 'the sacred' with any particular organised religion. Rather, they should be thought of as directing their attack on the culture or process of secularisation that leaves no place for the sacred as an important value that needs to be taken into account in our public and private lives. 
Liberals, on the other hand, would like to see religion as a matter for the individual in the private sphere (which they can then comfortably defend) but they do not want it as a public matter in the political sphere. This becomes most problematic when religions - other than individualised Protestantism and Catholicism - enter liberal societies, since often they will take the position that religious adherence is not about the privatised practices of the individual, but about the provision of a total environment in which the religious life can be led. Where the sacred is directly tied to a specific religion, as in Islam, it would appear then that there is less scope to negotiate the sacred. However, as Kuranda Seyit argues, there has been a long history of legitimate dissent within Islam, culminating in attempts by modern Islamic scholars to develop a position that is 'authentically Islamic and effectively modern' (chapter 5). Like Rutland and Lamb, scholars such as Omid Safi and Tariq Ramadan identify fanatic fundamentalists as the real blasphemers, and call for Muslims to wrestle with their faith and to reject traditionalism that is embraced for the sake of traditionalism. Nevertheless, there are strong social tendencies, especially in the Salaf movement, in Indonesia, Afghanistan, Pakistan and Saudi Arabia, which resist critical debate, calling for the strict observance of Shari'a law. Seyit, however, is confident that the history of critical thought within Islam, will prevail over fundamentalism.

\section{Sacrilege and the sacred}

To have sacrilege we must have the sacred, and how the sacred is construed will determine how sacrilege is construed. In chapter 6, following Durkheim, we argue that even secular societies, such as Australia, hold some events, places and things sacred, and perceive attacks on them as sacrilegious. Durkheim posed that the state, the individual and property could all be seen as sacred in contemporary societies, in that they are set aside and protected by interdictions. We argue that one way of explaining the profound reaction of the public and the legislature to the theft of the Australian coat of arms from Parliament House is in terms of an affront to the sacred. For Durkheim, those things that are constituted as sacred hold that character by virtue of the power relations of society that act to defend them. In contrast to earlier contributors to this volume, we present the experience of the sacred as a social, rather than personal event, and to the extent that it exists universally, as a characteristic of societies, and not of human beings.

In this vein, Colin Tatz explores the political constructions of the sacred (chapter 7). In particular, he explores the sacrality of the memorials to holocaust victims and to other peoples subjected to ethnic cleansing. In his analysis, sacrilege and blasphemy are irreverence towards persons or places held in high regard as a consequence of horrific acts perpetrated there or on them, and culminate in genocide denial - the attempt to erase from history knowledge of holocausts. 
The question of what constitutes sacrilege is also at the heart of Dianne McGowan's paper, which explores historical and cross-cultural variations in the treatment of the dead human body (chapter 8). At this historical juncture the body is 'sacred' in Western societies, though this has not always been the case, nor has it always been the case for all bodies. In the eighteenth and nineteenth centuries the bodies of criminals and of the poverty stricken who could not afford a funeral were used for anatomical experiments in the newly developed medical schools. With the passing of the Anatomy Act of 1832, the West entered the current phase of protecting the body in death. How then to accommodate contemporary cultures where the body in death is, as part of religious practice, dismembered and left to carrion eaters in the open? Could Australia accommodate the use of parts of the body, such as the head (sometimes of people newly dead) in religious ceremonies, as Tibetans do? Moreover, what does it say about Western culture when it exhibits these religious artefacts of Tibetan culture, as art in museums. As McGowan points out, when this occurs, the artefacts are sanitised of their religious function, allowing us to see them in aesthetic ways rather than being offended by them. In a similar way, Liam Dee argues that in capitalist economies the sacred becomes commodified and used as a marketing tool (chapter 9). Indeed some religious leaders, such as the Dalai Lama, are willing sell their religious prestige to multinational companies. The processes of aestheticisation and commodification, which substitute the value of the sacred for more 'acceptable' or profane commercial values, may be considered part of the process and culture of secularisation.

\section{The state and tolerance}

Ian Hunter discusses how, in European Catholicism, the sacred is the presence of a transcendental God on earth, whose presence is mediated by specific individuals, practices and places (chapter 10). It is this that makes other places, individuals and practices profane. Sacrilege is the abuse or violation of sacred individuals, places or practices. Crossing the boundary of the sacred and profane is where sacrilege occurs. Where this boundary is also the boundary of a community - of communicants - then sacrilege threatens the community itself and results in violent self-protective responses by the community. In early Modern Europe, Christianity and the political community were one, and the religious and political community was one. Hence sacrilege was both a transgression against God and a crime, enshrined in canon and Roman law across Europe, under the centralised authority of the papacy. Sacrilege was then linked not just to the transgression of the sacred but to heresy, blasphemy and witchcraft. Those outside the community threatened not just the civil survival of the community but also the community's ability to communicate with God.

As Hunter shows, the bloody sectarian conflicts of early Modern Europe were calmed and resolved in different ways across Germany, France and England. 
However, there are some features in common that can be identified. There was the gradual acceptance of European public law as the language for negotiating peace. Jurists came to accept the permanency of heresy, notwithstanding the attitude of church leaders. Religious truth was dropped as a criterion for peace in treaties and social peace given priority. This meant that the political domain was secularised. The church was to pursue salvation, the state social peace. This development was backed up by the 'spiritualisation' of religion. In this movement the individual's relationship to God became a matter of their personal spirituality, and not tied to orthodoxy or membership of the church. Hence, with the changing definition of the sacred, the nature of sacrilege changed. The outcome was that individuals could hold and develop a range of personas: Christian and citizen, while the state, with no religious objectives of its own, provided a space for voluntary religious association.

However, it does not follow from this that the culture of secularisation is a result of the separation of church and state. We expect the separation of the church and state, and increasing levels of education and industrialisation, will be accompanied by a decrease in religious dogmatism. In short, we expect that the benefits of modernity will lead to greater toleration of religious and ethnic differences, and therefore peace within and between nations. Yet, as Riaz Hassan shows in his contribution to this volume, modernity and the separation of the church and state does not necessarily lead to a decrease in religious commitment and to the secularisation of society (chapter 11). Rather, the secularisation of the state may be accompanied by an increase in private commitment to religious values. ${ }^{10}$ Hassan's research, conducted in seven Muslim countries, shows that there are paradoxical relations between religion and modernity. Conventional sociological wisdom, the secularisation thesis, argues that with modernisation comes secularisation and privatisation of religious beliefs, with religion increasingly losing its significance. However Hassan's findings suggest that where religion plays a strong role in the provision of services in modern societies, there may be higher levels of personal religious commitment. This research, if correct, has implications in relation to domestic policy. If modernity and the separation between the state and religion increases rather than decreases people's personal commitment to religious 'truth', the policies of toleration and multiculturalism may create the conditions for the kind of dogmatism and domestic conflict for which they are supposed to be the cure.

\section{A tolerant society?}

As a policy, freedom of religion has been understood as providing a 'negative freedom' from interference in religious beliefs or worship. ${ }^{11}$ Unsurprisingly, the process of democracy may place pressures on the state to be less tolerant of minority positions or to impose particular views of morality. For example, in recent political debates over gay marriage and abortion, people holding Christian 
beliefs may be seen as attempting to impose a particular religious conception of the sanctity of marriage and of life on other members of society. However, the structures that maintain a Christian domination of the moral norms of the state may not be explicitly stated in legislation. Wherever the law refers to 'community standards', it appears to refer to Christian values. For example, until recently in the United States of America, it was argued that laws forbidding the use of peyote did not impede religious freedom as drug laws were not laws that were directed towards religion. Such inexplicit domination may regulate the expression of religious belief in all areas of life, and law and social policy may be used as a means of regulating minority religions or sects. ${ }^{12}$ The issue here is not merely that the law forbids some kinds of actions. The law must say something. But there is a problem where the law, or its application, unreflectingly fails to respect religious beliefs in areas that it has the capacity to do so, or is used as a form of harassment. ${ }^{13}$ Inexplicit domination may reflect a systematic intolerance. Both explicit and inexplicit intolerance may be grounds for criticism of the state, and are one obvious cause of discontent for people belonging to minority religions.

On the surface, religious freedom and tolerance are hallmarks of liberal societies, and often-enshrined in constitutions, and enshrine the state as an arbiter of religious disputes. But it can be shown that the state's tolerance is a tolerance to major religions in the Christian-Judaic tradition and that it will over-ride the impact of believers' views where it regards those views as departing from what it considers community values. In dealing with the disposition of property left in wills, the courts use the standard of the wise and just testator to evaluate the fairness of the way in which an estate is bestowed, particularly where it benefits a religious group over a living relative or dependant. Thus, the principle on which the state operates will most likely disadvantage a minority group's religious convictions.

Pauline Ridge points out that appeals against wills can be carried out under the Family Provision Act 1982, whereby the applicant can challenge the distribution of the estate on the grounds, essentially, of financial need (chapter 12). The test the court applies is whether the disposition of the estate accords, in the court's view, with the judgment of 'a wise and just testator', in effect, in accord with community standards. Ridge shows in her analysis that the courts will over-ride testamentary gifts based on strong religious beliefs, since it will be unlikely for the testator's bequest to be upheld in the face of the normative and idealised model of a testator used by the court. Ridge explains that people who hold strong religious convictions are labelled 'obdurate believers', that is, as believers who are guided by religious conviction to the exclusion of other concerns. This applies not only to minority religions, but, for example, to members of mainstream religions who use their beliefs as a way of disentitling their children. Notwithstanding this, overall the standards of law reflect the dominant religious groups in society. Indeed, as Ridge points out, biblical stories (the prodigal son) 
have been used in court decisions to justify the overturning of a will. In this case, as she puts it, 'the general community, knowingly or unknowingly, upholds an ideal of parenthood that reflects Christian teaching'. In short, Ridge demonstrates that the courts will accept testamentary gifts motivated by religious belief only if they conform to the model of the wise and just testator, as determined by community standards. Ridge points out that there is far less likelihood of a challenge to religions stemming from Judaism - at least the dominant ones - since they incorporate in their teachings the responsibility of parents to provide for their family and children.

These problems of domination are not exclusive to Australia or Western democracies, as Colin Noble demonstrates in his examination of Catholicism in Japan (chapter 13). Under the Japanese constitution there is a separation of church and state, yet when the Emperor died in 1989, the state spent large sums of public money on his religious funeral. Japanese Christians mounted a legal challenge through the courts as they attempted to prevent the state from defining the realm of the sacred. However, the consequence was the opposite of what they hoped to achieve. In the presence of open hostility and indifference to their claims, Christians experienced further marginalisation, and the state strengthened its hold on the definition of the sacred.

\section{The future-openness and dogmatism}

What form can a dialogue between believers and non-believers take? Nietzsche, in his famous critique of Christianity, argued that all religion was a form of self-deception that leads to epistemic closure. Whereas the standard philosophical critique of religion has been, as in Hume, 'evidential atheism', that there is not enough evidence to justify the belief in a god, Nietzsche's critique is based on an 'atheism of suspicion', which questions the possibility of truthfulness in believing, constructing belief as a self-serving lie of a subservient group. Thus, the atheism of suspicion would seem to create an impasse for any dialogue. Yet, Winifred Lamb argues that the atheism of suspicion can be used by believers to check the drift into the support for an organised religion at the expense of the truth, or the slide to idolatry rather than worship (chapter 14). Lamb argues that Nietzsche's critique alerts believers to the easy drift to servility in prayer, prayer that is a form of bargaining with God, rather than the self-surrender that all religious traditions urge that it should be. She argues against a form of faith that she calls a form of 'cheap grace': the certainty that one has found the 'truth'. Rather, against fundamentalists, and drawing on the work of theologians such as Bonhoeffer, Merton and Moltmann, she suggests that applying Nietzsche's thought as a scalpel to one's own beliefs is central to the religious vocation. As she concludes: 'suspicion can provide a creative spur to religious self understanding', taking the philosophy of religion closer to religion. 
Similarly, St John argues for a reframing of religion such that the sacred is not identified with any specific set of beliefs, but as an ontological attribute of human beings (chapter 15). This conceptual step moves debates about sacrilege and blasphemy away from problems of cultural relativism towards what she describes as the universal human capacity to experience the holy. Sacrilege and blasphemy are affronts to this capacity to experience awe in the face of existence. A tolerant society is one where this capacity for awe is respected and defended.

As political theorists have pointed out before us, 'respecting diverse beliefs' cannot mean treating people as if their religious beliefs were of no consequence. ${ }^{14}$ But respecting beliefs does not mean that a judgment needs to be made about the truth of those beliefs, or that the state needs to enter disputes about religious dogma. Toleration in a multicultural society needs to be understood as more than a negative liberty. If Australia and other multicultural nations are to maintain peaceful societies, the religious values held by individuals and communities must be acknowledged and negotiated as social and political 'realities'. The sacred can literally be negotiated, as Hal Wootten argues (chapter 16). He documents how a secular state can balance the relationship between Aboriginal claims to sacred land with the economic imperatives of white Australians. At the core Wootten suggests that the very fact that the Aboriginal and Torres Strait Islander Heritage Protection Act, 1984, does not use the word sacred (rather it refers to an 'area of particular significance to Aboriginals') has meant that cases could be adjudicated without entering into evaluation of the beliefs of Aboriginals. Wootten also points out that the negotiation of specific claims is not much different from a myriad of choices that people make daily: it is not a special case. The case of land rights involves only a recognition that the Aboriginal group in question holds specific beliefs about that land and that we should recognise the sincerity of those beliefs and respect them. In this, the role of the state is to negotiate the sacred, and it can fulfil this role precisely because it is secular, liberal and committed to protecting cultural identity.

In Australia, the Mabo case, and more recent Native Title legislation, has meant that indigenous religions are not only recognised, but their maintenance is recognised as a human right and is a requirement for land claims. Under the Aboriginal and Torres Strait Islander Heritage Protection Act, 1984, sacred sites are protected as long as groups can show an ongoing connection to the land. As in the Hindmarsh Bridge case, an ongoing connection may be difficult to prove, and hotly contested. Yet overall, this experience provides us with a way of understanding what it might mean to respect religious beliefs and to acknowledge them as being of consequence, without having to accept them as true. In the resolution of such cases, we do not question the truth of Aboriginal beliefs about what is sacred, but acknowledge that such beliefs and values compete with other interests and values, such as public safety or economic development. 


\section{Conclusion}

Sacrilege and blasphemy are contested concepts, dependent on the definition of the sacred. Within the social sciences, and as the papers in this volume illustrate, the Durkheim-James debate is based on the different constructions of the sacred. This may be either as an individual perception of an overwhelming sense of the existence of God, or as the product of society itself, manifest in beliefs of the existence of the sacred.

What is clear from the contributions to this volume is that religion will remain a central aspect of modern and modernising societies. Whether embedded in the laws of secular states such as Australia, or manifest in more private devotion in the states of south-east Asia, despite the predictions of many early sociologists of religion, it has not, and is not becoming less of a social, political and cultural force. Equally though the implicit assumption of these early works - that religious belief was by definition beyond negotiation and was by definition totalitarian -- has been shown not to be the case. Religious tolerance has been both expressed and practised. Between devout Muslims, Hindus, Jews and Christians there is scope for dialogue, reconciliation and negotiation.

At the same time, the complexity of this debate has to be understood within the paradox of Australian multiculturalism. This, while seeking to foster social cohesion, also promotes cultural uniqueness. Again, as this volume illustrates, contributors from a range of cultural and political backgrounds have demonstrated by their openness, their commitment to dialogue and their understanding of their faith as contributing to a harmonious society, that a space does exist. That negotiation is possible, and a culturally and religiously pluralistic society is a viable option. In short, while there will be no easy resolution of the negotiation of the sacred, nevertheless as the contributors to this volume demonstrate, it can be achieved and it must be constantly sought after.

\section{ENDNOTES}

1 'The Commonwealth shall not make any law for establishing any religion, or for imposing any religious observance, or for prohibiting the free exercise of any religion, and no religious test shall be required as a qualification for any office or public trust under the Commonwealth'. At the same time the Australian constitution of 1901 is framed in terms of Christianity, 'humbly relying on the blessing of Almighty God'.

2 King, P. 1976, Toleration, London, Allen and Unwin, p. 77.

3 Maddox, M. 1999-2000, Indigenous Religion in Secular Australia, Parliament of Australia, Parliamentary Library Research Paper 11, p. 3.

4 Maddox, 1999-2000, p. 3.

5 Bouma, G. 1999, 'Social Justice Issues in the Management of Religious Diversity in Australia', Social Justice Research, vol. 12, no. 4, p. 288.

6 Bouma, 1999, p. 293.

7 Corr, R. 2000, 'Asians, Muslims and "Authentic Australians": Neoracism Down Under', Paper presented at Challenges of Immigration and Integration in the European Union and Australia, Centre for European Studies, The Australian National University. 
8 An exception is Fisher, A. and H. Ramsay, 2000, 'Of Art and Blasphemy', Ethical Theory and Moral Practice, vol. 3, pp. 137-67.

9 New South Wales Law Reform Commission, 1994, Report 74, Blasphemy, pp. 9-10.

10 See also Hassan, Riaz 2003, Faithlines: Muslim conceptions of Islam and Society, Karachi, Oxford University Press.

11 Murphy, Andrew R. 1997, 'The Uneasy Relationship between Social Contract Theory and Religious Toleration', The Journal of Politics, vol. 59, no. 2, pp. 368-92, p. 370.

12 Recent research into the sociology of social control has attempted to theorise the ways in which inexplicit domination occurs, see Richardson, James T. 2004, Regulating Religion: Case Studies from Around the Globe, Kluwer Academic Publishers.

13 For example, Magistrate Gregory Levine suggested that in the removal of children from the Christian Evangelical group, The Family, in 1992, authorities acted against the sect in something like a form of class action. <www.thefamily.org/dossier/legal/australia.htm> viewed January 2005.

14 Jones, Peter 1990, 'Respecting Beliefs and Rebuking Rushdie', British Journal of Political Science, vol. 20, no. 4, pp. 415-37, p. 429. 